\title{
Numerical study of bed slope change effect of circular channel with side weir in supercritical flow conditions
}

\author{
Hamed Azimi ${ }^{1,2} \cdot$ Saeid Shabanlou ${ }^{3}$ (D) \\ Received: 7 January 2018 / Accepted: 11 September 2018 / Published online: 20 September 2018 \\ (c) The Author(s) 2018
}

\begin{abstract}
In this numerical study, the pattern and the field of the passing flow through circular channels with the side weir in supercritical flow conditions are simulated using the FLOW-3D model. First, the numerical model results are validated with the experimental data and a good agreement between the results is obtained from the numerical simulation and the experimental data. Then, the effects of the slope change of the circular channel bed on the flow free surface, the discharge of the side weir, the Froude number at the end of the side weir upstream, the discharge coefficient of the side weir, the specific energy and the slope of the S3 profile are investigated. In this study, the flow field turbulence and variations of the free surface computational field are simulated using the RNG $k-\varepsilon$ turbulence model and the volume of fluid (VOF) method, respectively. In practice, transmission channels used in irrigation networks and urban sewage disposal systems are steep. Therefore, the main purpose of this computational fluid dynamics (CFD) study is investigating the effect of the bed slope change of circular channels with side weir in supercritical flow conditions on the pattern and the structure of these types of flows.
\end{abstract}

Keywords Supercritical flow $\cdot$ Circular channel $\cdot$ Side weir $\cdot$ Bed slope of main channel $\cdot$ Numerical simulation

\section{List of symbols}

$A_{x}, A_{y}, A_{z} \quad$ Fractional areas open to flow $\left(\mathrm{m}^{2}\right)$

$A \quad$ Cross-sectional area $\left(\mathrm{m}^{2}\right)$

$C_{d} \quad$ Discharge coefficient (-)

$C_{u} \quad$ Constant coefficient (-)

$D \quad$ Channel diameter (m)

$E_{1} \quad$ Specific energy at section 1 in the main channel (m)

$E_{2} \quad$ Specific energy at section 2 in the main channel (m)

$F \quad$ Fluid volume fraction in a cell (-)

$F_{1} \quad$ Froude number at beginning of side weir on axis of main channel (-)

$f_{x}, f_{y}, f_{z} \quad$ Viscous accelerations $\left(\mathrm{m} / \mathrm{s}^{2}\right)$

Saeid Shabanlou

Saeid.Shabanlou@gmail.com

Hamed Azimi

Azimi86Hamed@gmail.com

1 Department of Civil Engineering, Razi University, Kermanshah, Iran

2 Environmental Research Center, Razi University, Kermanshah, Iran

3 Department of Water Engineering, Kermanshah Branch, Islamic Azad University, Kermanshah, Iran

$\begin{array}{ll}G_{x}, G_{y}, G_{z} & \text { Body accelerations }\left(\mathrm{m} / \mathrm{s}^{2}\right) \\ g & \text { Acceleration gravity }\left(\mathrm{m} / \mathrm{s}^{2}\right) \\ k_{t} & \text { Turbulence kinetic energy }\left(\mathrm{m} / \mathrm{s}^{2}\right) \\ L & \text { Side weir length }(\mathrm{m}) \\ P & \text { Side weir height }(\mathrm{m}) \\ p & \text { Pressure }\left(\mathrm{N} / \mathrm{m}^{2}\right) \\ Q_{1} & \text { Discharge at section } 1 \text { in the main channel } \\ & \left(\mathrm{m}^{3} / \mathrm{s}\right) \\ Q_{w} & \text { Discharge over the side weir }\left(\mathrm{m}^{3} / \mathrm{s}\right) \\ q & \text { Discharge per unit length of the side weir } \\ & \text { (m } 2 / \mathrm{s}) \\ R_{\mathrm{SOR}} & \text { Mass source }(-) \\ S_{f} & \text { Friction losses }(-) \\ S_{0} & \text { Bed slope of the channel }(-) \\ T & \text { Width of the channel at the water surface }(\mathrm{m}) \\ T_{l \mathrm{en}} & \text { Turbulent length scale (m) } \\ t & \text { Time (s) } \\ u, v, w & \text { Velocity components (m/s) } \\ V_{F} & \text { Fractional volume open to flow (-) } \\ X, Y, Z & \text { Cartesian coordinate directions (m) } \\ x & \text { Distance from upstream of the weir (m) } \\ z & \text { Depth of the flow (m) } \\ z_{1} & \text { Depth of the flow at section } 1 \text { in the main } \\ & \text { channel (m) } \\ & \end{array}$

$G_{x}, G_{y}, G_{z} \quad$ Body accelerations $\left(\mathrm{m} / \mathrm{s}^{2}\right)$

$g \quad$ Acceleration gravity $\left(\mathrm{m} / \mathrm{s}^{2}\right)$

$k_{t} \quad$ Turbulence kinetic energy $\left(\mathrm{m} / \mathrm{s}^{2}\right)$

$L \quad$ Side weir length (m)

$P \quad$ Side weir height (m)

$p \quad$ Pressure $\left(\mathrm{N} / \mathrm{m}^{2}\right)$

$Q_{1} \quad$ Discharge at section 1 in the main channel $\left(\mathrm{m}^{3} / \mathrm{s}\right)$

Discharge over the side weir $\left(\mathrm{m}^{3} / \mathrm{s}\right)$

$\left(\mathrm{m}^{2} / \mathrm{s}\right)$

Friction losses $(-)$

Bed slope of the channel (-)

Width of the channel at the water surface $(\mathrm{m})$

Turbulent length scale $(\mathrm{m})$

Time (s)

Fractional volume open to flow (-)

Cartesian coordinate directions (m)

Distance from upstream of the weir (m)

channel (m) 


$\begin{array}{ll}z_{2} & \begin{array}{l}\text { Depth of the flow at section } 2 \text { in the main } \\ \text { channel }(\mathrm{m})\end{array} \\ \alpha & \text { Velocity distribution coefficient } \\ \varepsilon_{t} & \text { Turbulence dissipation rate }\left(\mathrm{m}^{2} / \mathrm{s}^{3}\right) \\ \theta & \text { Slope of the } \mathrm{S} 3 \text { profile }(\mathrm{rad}) \\ v_{t} & \text { Turbulent kinematic viscosity }\left(\mathrm{m}^{2} / \mathrm{s}\right) \\ \rho & \text { Fluid density }\left(\mathrm{kg} / \mathrm{m}^{3}\right)\end{array}$

\section{Introduction}

A side weir is installed on the side wall of the main channel in order to adjust the flow level. Also, flow within open channel along the side weir is considered as spatially varied flow (SVF) with decreasing discharge. Moreover, many experimental and analytical researches and studies have been conducted on the flow pattern of these types of structures. There are so many studies on the flow within rectangular channels along the side weir carried out by various researchers. For example, Ackers (1957), Nandesamoorthy and Thomson (1972), Yu-Tech (1972), RangaRaju et al. (1979), Hager (1982), Uyumaz and Smith (1991), Jalili and Borghei (1996), Borghei et al. (1999), Khorchani and Blanpain (2004), Vatankhah and Bijankhan (2009), Emiroglu et al. (2010, 2011), Bagheri and Heidarpour (2012), Novak et al. (2013), Mohammed (2013) studied the hydraulic behavior of the side weir flow. Additionally, various studies were carried out related to trapezoidal channels along the side weir. For instance, Cheong (1991) presented an equation in order to compute the discharge coefficient of side weirs located on trapezoidal conduit. Also, Vatankhah (2012a) proposed an analytical solution to predict the variations of flow free surface along the side weir for subcritical and supercritical flow regimes. For U-shaped channels along the side weir, Uyumaz (1997) using the specific energy principles and the finite difference method provided an analytical solution for predicting variations of the flow free surface profile along the side weirs. Uyumaz, by conducting some experiments in both subcritical and supercritical flow conditions, showed an acceptable agreement between the experimental and mentioned method results. Vatankhah (2013) introduced a semi-analytical solution for predicting variations of the longitudinal profile of the flow free surface along the side weirs located on U-shaped channels. The method was based on the energy principles obtained by integration solution. Additionally, for triangular channels along the side weirs, Uyumaz (1992) presented an analytical solution for calculating variations of the flow free surface along the side weirs in subcritical and supercritical flow conditions. In addition, Vatankhah (2012b) using integration and the principles of specific energy solved the governing dynamical equation on the passing flow over side weirs located on triangular channels. Vatankhah's analytical method predicts the free surface flow profile along the side weir with an acceptable accuracy. Moreover, channels with circular cross section are used in urban sewage disposal networks and drainage systems. In association with circular channels along the side weirs, Allen (1957) conducted an experimental study on the hydraulic behavior of the passing flow over rectangular side weirs. Uyumaz and Muslu (1985) by assuming that the flow in the main channel is two dimensional and the pressure is hydrostatical predicted the longitudinal profile of the flow free surface along the side weir and the passing flow over it using the finite element method. Their analytical method for both supercritical and subcritical flow conditions was validated by experimental results. Ramamurthy et al. (1995) through the two-dimensional flow theory provided an analytical method for predicting the passing flow over a side weir located on a circular channel. They introduced the theoretical discharge coefficient of the side weir as a function of the geometric parameters of the side weir. Oliveto et al. (2001) investigated the characteristics of supercritical flow conditions along the side weirs located on circular channels. Their experiments have been focused on the local measurement of the flow output angle and the velocity along the side weir. In all experiments, the side weir upstream flow is subcritical and the flow along the side weir is supercritical. Vatankhah (2012c) by the incomplete elliptic integrals method and the specific energy principle provided a semianalytical solution for calculating the longitude profile of the flow free surface in both subcritical and supercritical flow conditions. In practice, it is possible that the flow along the side weir be supercritical. Many experimental and theoretical studies have been conducted on supercritical flows passing through channels with side weir. Hager (1994) provided an analytical method for supercritical flows passing through circular channels with side weir. His method is used in both flow conditions: with hydraulic jumps and without hydraulic jumps. He validated the obtained results from his analytical method by the experimental results obtained by other researches. Ghodsian (2003) investigated the passing supercritical flow over the side weir located on a rectangular channel. He introduced the elementary discharge coefficient of the side weir in supercritical flow conditions as a function of the ratio of the head above the weir to the weir crest height and the Froude number. Mizumura et al. (2003) provided an analytical solution for calculating the main channel discharge in a rectangular channel with side weir in supercritical flow conditions. Their analytical method was based on the energy principles, and the main channel discharge was introduced as a function of the Froude number. Pathirana et al. (2006) conducted an experimental study including investigation of the upstream specific energy, the discharge coefficient and the passing flow over the side weir in supercritical flow conditions for a rectangular channel equipped with a side weir. Using the specific energy principles and 
the regression analysis, they provided a relationship for calculating the discharge coefficient of side weirs in supercritical flow conditions. Rao and Pillai (2008) investigated the discharge coefficient of the side weir, the velocity in the main channel, the flow falling angle from the side weir and measured the flow depth along the weir by conducting an experimental study on a rectangular channel with side weir in supercritical flow conditions. Coonrod et al. (2009) investigated the effect of guide vanes on increasing the diversion flow rate over side weirs located on rectangular channels in supercritical flow conditions. In recent years, computational fluids dynamics (CFD) has been introduced as a powerful tool for understanding the hydrodynamic behavior of fluids and the interaction between the fluid and the structure. Also, many studies were carried out in order to simulate the flow field of main channels along the side weir. For example, Qu (2005) modeled three-dimensional (3D) changes of the flow in rectangular channels along the side weir using the $k-\omega$ turbulence model and the volume of fluid (VOF) scheme. Tadayon (2009) developed a numerical model to simulate the flow field within rectangular conduits along the side weir. The numerical model simulated the flow turbulence and variations of the flow free surface with the RSM turbulence model and the VOF method, respectively. Aydin (2012) using the FLUENT software simulated the flow free surface within a rectangular channel along the triangular labyrinth side weir by the VOF scheme. Aydin and Emiroglu (2013) using the ANSYS FLUENT software simulated the discharge capacity of labyrinth side weirs. They modeled the free surface changes by the VOF method and the flow turbulence by different turbulence models. Furthermore, they showed that the discharge coefficient increased by increasing the Froude number. Azimi et al. (2014) simulated the velocity field along the side weir in circular channels using RNG $k-\varepsilon$ and VOF scheme. Also, Azimi and Shabanlou (2015) modeled the flow pattern in triangular channels along the side weir. The effect of the Froude number was examined on the characteristics of the flow field.

Intense studies have been carried out on the application of numerical simulation in modeling engineering problems, with the number of such studies increasing every day. However, according to the literature, despite the importance of awareness about open channels along the side weirs in designing hydraulic structures, very few studies have focused on variations of slop bed. As a result, the current study is deemed preliminary in this direction.

In this numerical simulation, the flow field and the circular channel turbulence are simulated using the FLOW-3D model. In this numerical model, the free surface variations of the flow field are simulated by the VOF method and the flow turbulence is simulated using the RNG $k-\varepsilon$ turbulence model. In practice, circular channels used in sewage disposal networks are steep. Therefore, in this numerical study, the effects of increasing the main channel bed slope on the hydraulic behavior of supercritical flows along the side weirs are investigated.

\section{Governing equations}

In this numerical simulation, in order to solve the flow field of a non-compressible fluid in the Cartesian coordinate system, the continuity equation and the Reynolds-averaged Navier-Stokes equations are used as follows:

$V_{F} \frac{\partial \rho}{\partial t}+\frac{\partial\left(\rho u A_{x}\right)}{\partial x}+\frac{\partial\left(\rho v A_{y}\right)}{\partial y}+\frac{\partial\left(\rho w A_{z}\right)}{\partial z}=R_{\mathrm{SOR}}$
$\frac{\partial u}{\partial t}+\frac{1}{V_{F}}\left(u A_{x} \frac{\partial u}{\partial x}+v A_{y} \frac{\partial u}{\partial y}+w A_{z} \frac{\partial u}{\partial z}\right)=-\frac{1}{\rho} \frac{\partial p}{\partial x}+G_{x}+f_{x}$

$\frac{\partial v}{\partial t}+\frac{1}{V_{F}}\left(u A_{x} \frac{\partial v}{\partial x}+v A_{y} \frac{\partial v}{\partial y}+w A_{z} \frac{\partial v}{\partial z}\right)=-\frac{1}{\rho} \frac{\partial p}{\partial y}+G_{y}+f_{y}$

$\frac{\partial w}{\partial t}+\frac{1}{V_{F}}\left(u A_{x} \frac{\partial w}{\partial x}+v A_{y} \frac{\partial w}{\partial y}+w A_{z} \frac{\partial w}{\partial z}\right)=-\frac{1}{\rho} \frac{\partial p}{\partial z}+G_{z}+f_{z}$,

where $(u, v, w),\left(A_{x}, A_{y}, A_{z}\right),\left(G_{x}, G_{y}, G_{z}\right)$ and $\left(f_{x}, f_{y}, f_{z}\right)$ are the velocity components, the fractional area open to the flow, gravitational forces and accelerations due to the viscosity in $x$-, $y$ - and $z$-directions, respectively. Also $t, \rho, R_{\mathrm{SOR}}, p$ and $V_{F}$ are the time, the density, the term of the source, the pressure and the fractional volume open to the flow, respectively. In this numerical study, the RNG $k-\varepsilon$ turbulence model is used for simulating the flow field. Among turbulence methods, the RNG $k-\varepsilon$ turbulence model is more applicable. Furthermore, this turbulence model describes the flow behavior near the solid wall with a suitable accuracy. In the VOF model, the following continuity equation is solved to calculate the volume component:

$\frac{\partial F}{\partial t}+\frac{1}{V_{F}}\left(\frac{\partial}{\partial x}\left(F u A_{x}\right)+\frac{\partial}{\partial y}\left(F v A_{y}\right)+\frac{\partial}{\partial z}\left(F w A_{z}\right)\right)=0.0$,

where $F$ is the volume component of the fluid in a specified computational cell. If $F=0$, the cell is full of air, and if $F=1$ the computational cell is filled with the fluid, and if $0<F<1$ the cell contains air and water.

\section{Boundary conditions}

To solve the computational domain in this numerical study, the specified amounts of flow and depth are used in the inlet boundary conditions. Flow turbulence parameters at the entrance of the main channel are the turbulence kinetic 
energy and the turbulent dissipation rate which are calculated using Eqs. (6) and (7), respectively.

$k_{t}=\frac{3}{2}\left(v_{t} \cdot T_{\text {len }}\right)^{2}$

$\varepsilon_{t}=C_{u} \sqrt{\frac{3}{2}} \frac{k_{t}^{3 / 2}}{T_{\text {len }}}$

In these relationships, $v_{t}$ is the turbulence kinematic viscosity and TLEN is the length scale of the turbulence that in open channels is considered equal to $7 \%$ of the hydraulic diameter. $C_{u}$ is a constant value that in the RNG turbulence model is considered equal to 0.085 . In the main channel outlet boundary conditions, the specified amounts of the depth and the pressure are used. In this numerical simulation, in order to fall the flow over the weir and at connection location of the circular channel with the side weir a tank is installed. The dimensions of the mentioned tank and the used boundary conditions in it are shown in Fig. 1. At the outlet section of this tank, the outlet boundary condition is considered.

All of the solid walls including the side walls and the main channel bed are considered as the "wall" boundary condition. The nonslip condition is imposed to the wall boundary condition. At the wall boundary condition, the typical velocity

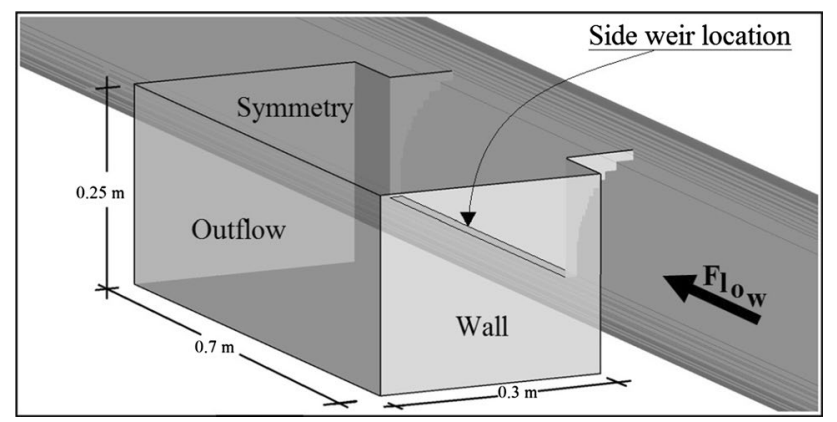

Fig. 1 Defined boundary conditions for connected tank to side weir in numerical model should be considered zero and there is no need to define turbulence parameters such as the turbulence kinetic energy and the turbulence dissipation rate. In this numerical study, the entire upper surface of the air phase is considered as the symmetry boundary conditions. In symmetry boundary conditions, the velocity change is zero across the boundary condition; thus, the turbulence is not generated.

\section{Experimental data}

The experimental data have been measured by Uyumaz and Muslu (1985). The laboratory model is composed of a circular channel with side weir. The circular channel is made of concrete, and the side weir is made of fiberglass panels. The length and the diameter of the main channel are considered equal to 10.9 and 0.25 , respectively. The side weir is installed on the circular channel side wall, and its length and height are 0.5 and $0.06 \mathrm{~m}$, respectively. In Fig. 2 the schematic layout of the circular channel with side weir in supercritical flow conditions used by Uyumaz and Muslu (1985) is illustrated.

In this numerical study, the whole computational domain is gridded by a non-uniform mesh block consisting of rectangular elements. In Table 1, the number of the used computational elements in the numerical simulation is shown.

In Fig. 3, the used gridding in the numerical simulation is shown. Due to the presence of big vortexes and big flow gradient at the connection point of the main channel and the side weir, the mesh size is considered finer than the other parts of the flow field. At the solid walls, the mesh size is also considered much finer. In other words, the distance of the first cell from walls is chosen somehow to prevent from calculations below the viscose region. So, the first node is placed where the dimensionless parameter $y^{+}$which is defined using Eq. (8), is greater than 30 .

$y^{+}=\frac{y_{1} u_{*}}{v}$,

where $y_{1}$ is the distance of the first node from the wall perpendicular to it, $u_{*}$ is the shear velocity of the wall and $v$

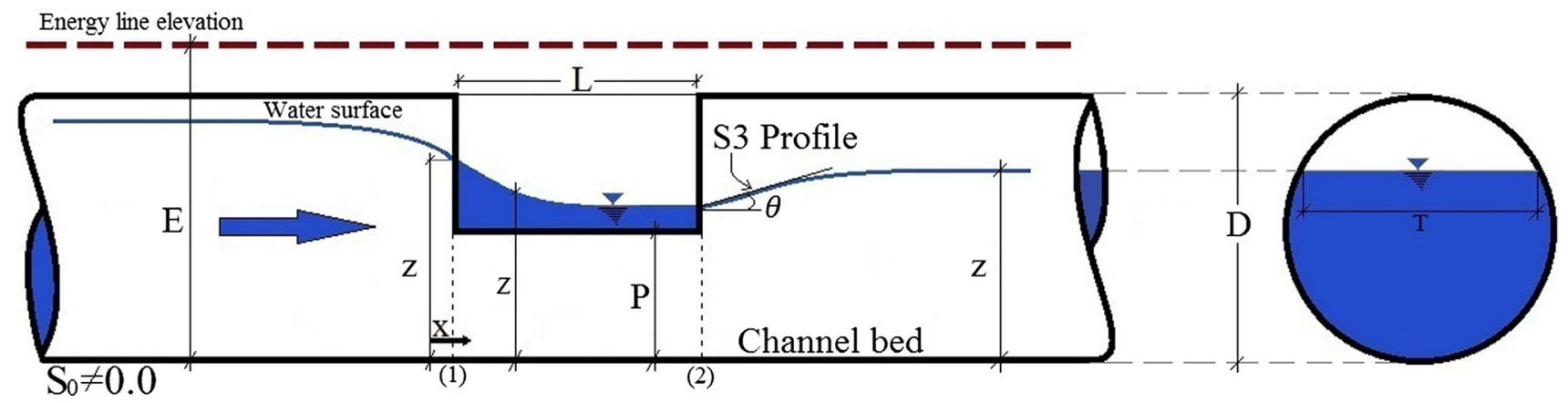

Fig. 2 Schematic layout of circular channel with side weir used by Uyumaz and Muslu 
Table 1 Number of computational cells used in numerical simulation

\begin{tabular}{lcll}
\hline Location & Direction $X$ & Direction $Y$ & $\begin{array}{l}\text { Direc- } \\
\text { tion } Z\end{array}$ \\
\hline Main channel & 196 & 60 & 58 \\
Tank & 60 & 30 & 58 \\
\hline
\end{tabular}

is the kinematic viscosity of the fluid. Also, the maximum adjacent cell size ratio in $x$-, $y$ - and $z$-directions are considered close to 1 . Therefore, the flow field is separated from the gridding by an optimized and independent mesh. In order to investigate the prediction accuracy of the numerical model, the average percent error (APE) of the flow free surface and the root mean square error percent (RMSE) are calculated using Eqs. (9) and (10), respectively:

$\mathrm{APE}=\frac{100}{N} \sum_{i=1}^{N}\left|\frac{R_{\text {(measured) }}-R_{\text {(simulated) }}}{R_{\text {(measured) }}}\right|$

$\mathrm{RMSE}=100 \times \sqrt{\frac{1}{N} \sum_{i=1}^{N}\left(R_{\text {(measured) }}-R_{\text {(simulated) }}\right)^{2}}$

where $R_{\text {(measured) }}$ and $R_{\text {(simulated) }}$ are the laboratory and simulation results, respectively. In Table 2 , the characteristics of griddings used in the numerical modeling, APE and RMSE, for the simulated free surface profile are shown. As shown, the difference between griddings 4 and 5 is negligible and gridding 4 is chosen to separate the computational field.

\section{Results and discussion}

\section{Validation}

In this numerical simulation, the experimental results obtained by Uyumaz and Muslu (1985) are used to validate the numerical model results. The main channel inlet discharge value, the flow depth at the upstream end, the flow depth at the downstream end of the side weir are measured $0.025 \mathrm{~m}^{3} / \mathrm{s}, 0.1164 \mathrm{~m}$ and $0.0806 \mathrm{~m}$, respectively. In

Table 2 Characteristics of griddings, APE and RMSE of simulated free surface profile

\begin{tabular}{llll}
\hline Meshing & Number of cells & APE (\%) & RMSE (\%) \\
\hline 1 & 85,500 & 8.507 & 7.351 \\
2 & 189,920 & 5.036 & 4.744 \\
3 & 400,896 & 3.279 & 2.014 \\
4 & 786,480 & 1.193 & 0.182 \\
5 & 936,448 & 1.191 & 0.181 \\
\hline
\end{tabular}

Fig. 3 Computational field gridding a $3 \mathrm{D}$ view, $\mathbf{b}$ cross section, c plan

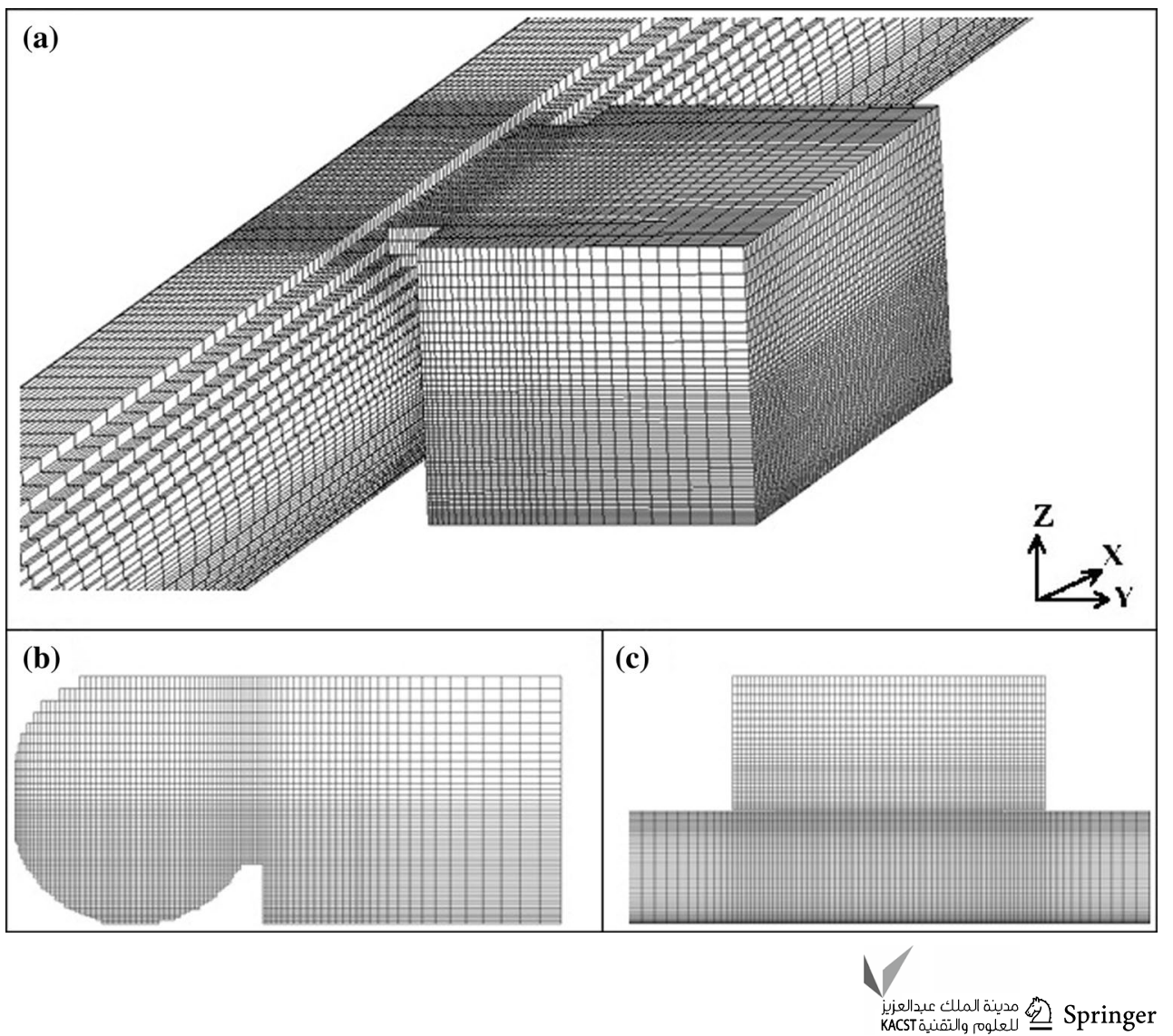


the experimental model used by Uyumaz and Muslu, the main channel slope has been considered 0.005 and the flow within the main channel is in supercritical flow conditions. In Fig. 4, the comparison between the simulated and experimental free surface is shown. The values of APE and RMSE of the simulated free surface profile were calculated $1.193 \%$ and $0.182 \%$, respectively. Therefore, the numerical model simulates the flow with an acceptable accuracy, so that according to the supercritical flow pattern, the flow depth along the side weir decreases from the upstream end toward the downstream end.

Uyumaz and Muslu (1985) suggested the discharge per unit length of the side weir located on a circular channel using the following relationship:

$-\frac{\mathrm{d} Q_{w}}{\mathrm{~d} x}=q=C_{d} \sqrt{2 g(z-P)}(z-P)$

where $Q_{w}$ is the passing discharge over the side weir, $x$ is the longitudinal distance from the beginning of the weir, $\frac{\mathrm{d} Q_{w}}{\mathrm{~d} x}$ or $q$ is the discharge per length unit of the weir, $g$ is the gravitational acceleration, $P$ is the elevation of the side weir and $z$ is the flow depth. Thus, the side weir discharge coefficient $\left(C_{d}\right)$ is calculated as follows:

$C_{d}=\left(\frac{Q_{w}}{L \sqrt{2 g}(z-P)^{3 / 2}}\right)$

Uyumaz and Muslu have provided empirical Eq. (13) to calculate the discharge coefficient of side weirs located on circular channels in the supercritical regime.

$$
\begin{aligned}
C_{d}= & -(0.046+0.0054 \sqrt{1.67 L / D-1}) F_{1} \\
& +(0.24+0.021 \sqrt{1+35.3 L / D})
\end{aligned}
$$

This relationship is a function of the side weir length to the main channel diameter $(L / D)$ and the Froude number of the upstream end of the side weir $\left(F_{1}\right)$. In Table 3, the Froude numbers and the discharge coefficient values obtained from the experimental and numerical results are compared. The

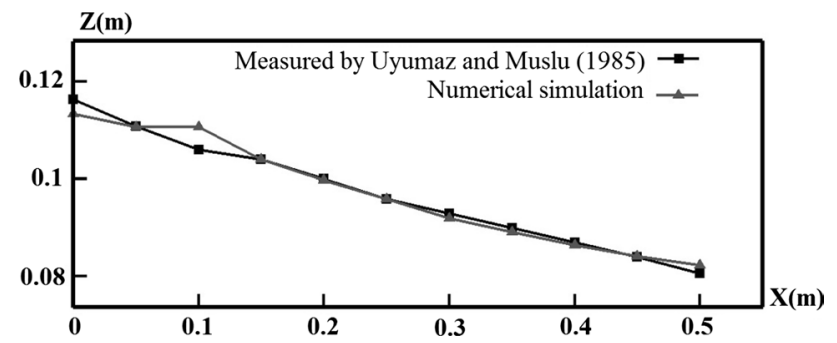

Fig. 4 Comparison between free surface changes of numerical and experimental models relative error percent value is calculated by the following equation:

$\mathrm{REP}=100 \times\left|\frac{R_{\text {(measured) }}-R_{\text {(simulated) }}}{R_{\text {(measured) }}}\right|$

Equation (13) predicts the numerical and experimental discharge coefficients very close, because this relationship is the only function of the Froude number and the $L / D$ parameter. Uyumaz and Muslu (1985) have measured different values of the passing flow over the side weir for different passing discharges through the main channel and the experimental model with geometric characteristics of $(L / D=2),(P / D=0.24)$ and $\left(S_{0}=0.002\right)$. In Fig. 5 , the comparison of the results of the experimental and numerical in predicting the side weir discharge is shown.

As shown, the numerical model predicts the side weir discharge coefficient with high accuracy. To evaluate the accuracy of the numerical model, APE and RMSE values of the side weir discharge coefficient are calculated $4.61 \%$ and $0.022 \%$, respectively. Uyumaz and Muslu (1985) have calculated the specific energy level at the side weir upstream section equal to $17.99 \mathrm{~cm}$, while the numerical model has predicted the specific energy value at the side weir upstream section equal to $18.67 \mathrm{~cm}$. The relative error percent value is calculated $3.8 \%$ that indicates high accuracy of the numerical model in predicting the specific energy value.

Table 3 Comparison of experimental and numerical Froude number and discharge coefficient

\begin{tabular}{llll}
\hline & Experimental & Numerical & REP (\%) \\
\hline$C_{d}$ from relationship (12) & 0.349 & 0.341 & 2.3 \\
$C_{d}$ from relationship (13) & 0.352 & 0.358 & 1.7 \\
$F_{1}$ & 1.22 & 1.1 & 9.8 \\
\hline
\end{tabular}

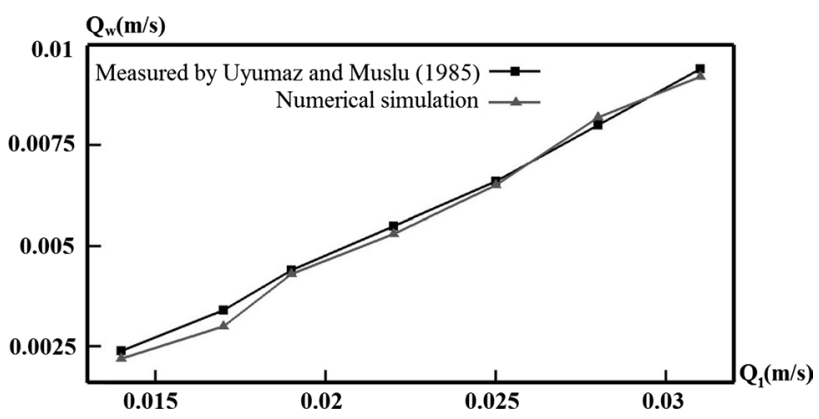

Fig. 5 Comparison of the experimental and numerical results of passing flow over side weir 


\section{Slope effects of flow field in main channel}

\section{Slope effect on flow free surface}

Several researchers such as Subramanya and Awasthy (1972), El-Khashab (1975), Singh et al. (1994), Borghei et al. (1999) and Rao and Pillai (2008) investigated the main channel slope effects on the discharge coefficient of side weirs by conducting analytical and experimental studies. In practice, most of transmission channels used in irrigation and sewage disposal networks are steep. In this numerical study, the effects of increasing the main channel bed slope $\left(S_{0}\right)$ are investigated. In this numerical model, by increasing the channel bed, boundary conditions, gridding of the computational field and the hydraulic conditions of the model have been considered constant and the only parameter which has been changed is the main channel bed slope. In Fig. 6, the variations of the flow free surface along a side weir located on the main channel central axis are evaluated for three different slopes. As shown, by increasing the channel

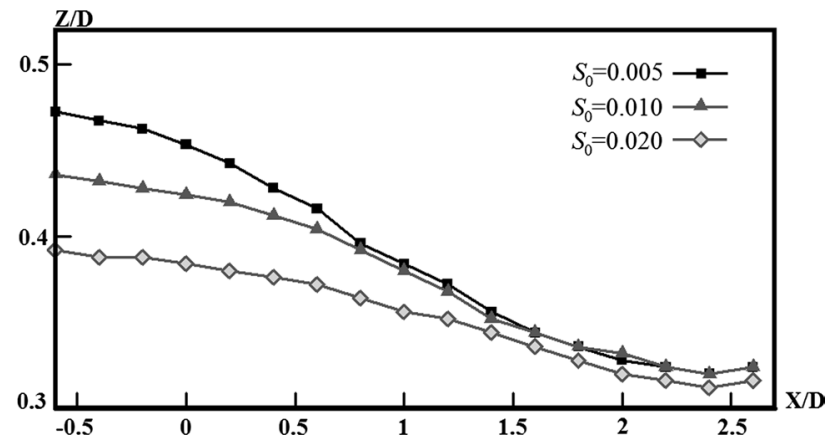

Fig. 6 Free surface changes along the side weir located on main channel central axis for different slopes bed slope, the water free surface drops, so that the steeper channel drops more. This drop at the side weir upstream is more than the downstream. By taking distance from the side weir location at the downstream end of the weir, the effects of increasing the channel bed slope on the flow free surface will be negligible.

In Fig. 7, the simulated transverse profiles of the flow free surface at three sections of the beginning, the middle and the end of the side weir are shown. At the beginning section of the side weir, the flow free surface decreases by increasing the channel bed slope and by advancing toward the side weir, the effects of increasing the slope will be negligible. Near the side weir and at the beginning section, a sudden drop occurs. At the middle of the side weir (section 2-2), this drop is less and at the downstream of the side weir (section 3-3) this drop increases.

In the numerical simulation, the main channel inlet discharge $\left(Q_{1}\right)$ is considered constant and by increasing the main channel bed slope, its effect on the passing flow over the side weir is investigated. In Table 4, discharge changes of the side weir $\left(Q_{w}\right)$, the Froude number $\left(F_{1}\right)$ and the discharge coefficient of the side weir $\left(C_{d}\right)$ versus the main channel slope increasing are shown. By increasing of the bed slope, the discharge over the side weir decreases. As shown in Table 4, by increasing the main channel slope, the Froude number upon the side weir upstream end increases and the discharge coefficient decreases (calculated by Eq. 12). Thus, the discharge coefficient of the side weir decreases by increasing the main channel bed slope.

\section{Specific energy}

Dynamic equations governing spatial variable flows with discharge reduction are solved using the energy
Fig. 7 Transverse profiles of simulated free surface for various slopes a section $1-1, \mathbf{b}$ section 2-2, c section 3-3
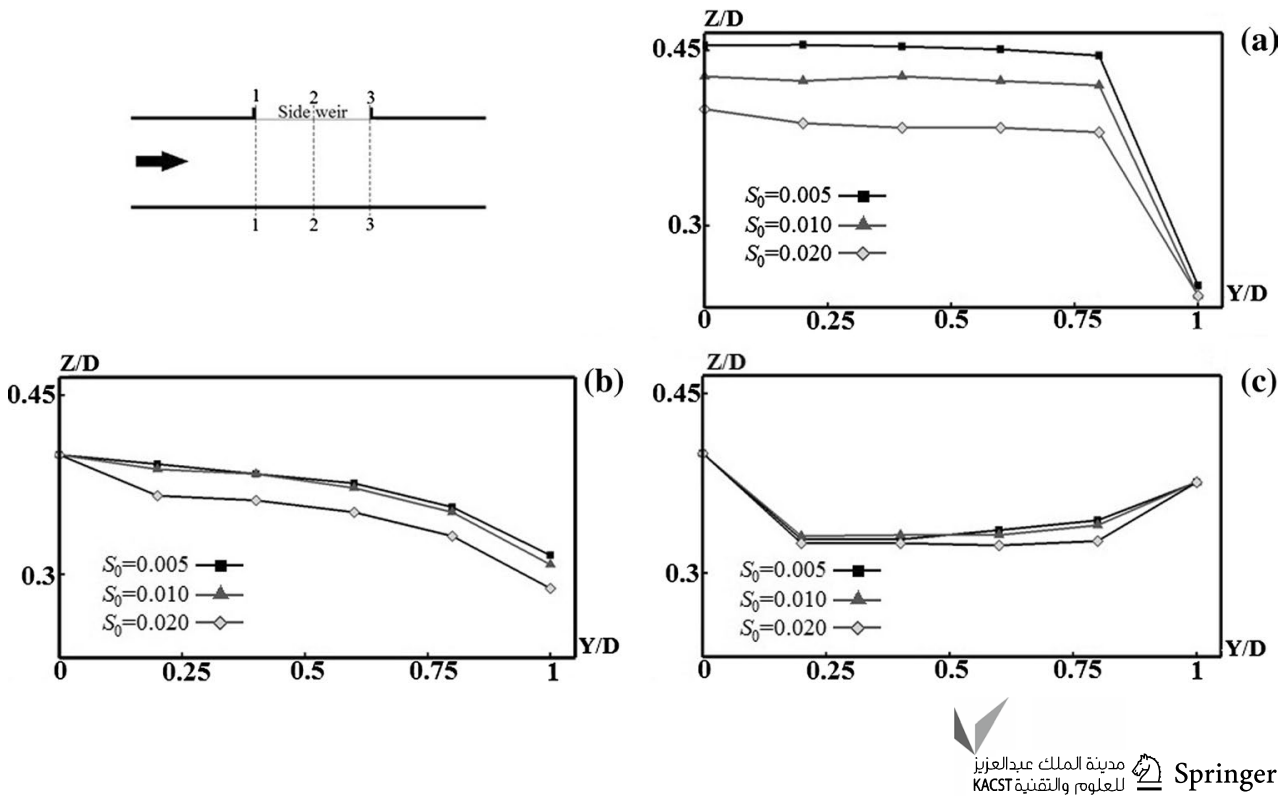
Table 4 Changes of $Q_{w}, F_{1}, C_{d}$ versus increasing of main channel bed $\left(S_{0}\right)$

\begin{tabular}{llll}
\hline$\left(S_{0}\right)$ & 0.005 & 0.01 & 0.02 \\
\hline$Q_{w}\left(\mathrm{~m}^{3} / \mathrm{s}\right)$ & 00,054 & 0.0045 & 0.0032 \\
$F_{1}$ & 1.1 & 1.22 & 1.46 \\
$C_{d}$ & 0.358 & 0.352 & 0.339 \\
\hline
\end{tabular}

conservation principle. The energy equation in each section of the channel (2) is calculated as:

$E=z+\alpha\left(\frac{Q_{1}^{2}}{2 g A^{2}}\right)$

where $(E)$ is specific energy, $(\alpha)$ is the velocity distribution coefficient, $\left(Q_{1}\right)$ is the discharge within the main channel and $(A)$ is the flow cross section.

Several theoretical and experimental studies related to the flow along the side weir and the specific energy have been conducted. Researchers such as Borghei et al. (1999), Muslu (2001), Muslu et al. (2003) and Vatankhah and Bijankhan (2009) expressed that if the side weir length is being short, the constant specific energy assumption is acceptable. The constant specific energy theory along the side weir is equivalent to this assumption, so that the friction loss $\left(S_{f}\right)$ is equal to the main channel bed slope $\left(S_{0}\right)$ or $S_{f}=S_{0}=0.0$. Several researchers such as El-Khashab and Smith (1976) and Borghei et al. (1999) by conducting different experiments expressed that the specific energy value along the side weir in supercritical flow conditions is almost constant. El-Khashab and Smith (1976) and Borghei et al. (1999) in their experimental studies estimated the difference between the specific energy at the side weir upstream and downstream 5\% and $3.7 \%$, respectively. Pathirana et al. (2006) and Rao and Pillai (2008) using the energy principles provided some relationships for calculating the side weir discharge coefficient. Pathirana et al. (2006) in their experimental results by comparing the specific energy at the side weir upstream and its downstream calculated the difference between $E_{1}$ and $E_{2}$ in supercritical flow condition about $3 \%$. In this numerical study, the constant specific energy principle along the side weir is investigated. In Fig. 8, the specific energy value at the upstream and downstream end of the side weir for different values of the passing flow through the main channel with the bed slope $S_{0}=0.002$ which has been measured by Uyumaz and Muslu (1985) is compared. The numerical model predicted the specific energy value along the side weir almost constant, and the energy loss along the side weir is negligible. The average difference of the specific energy at the upstream and the downstream of the side

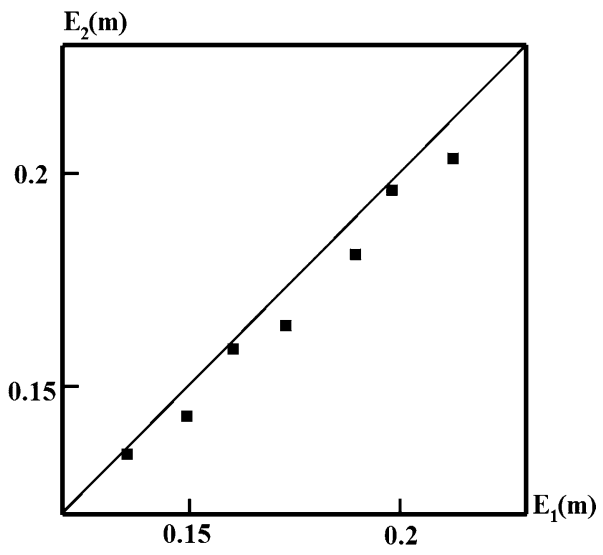

Fig. 8 Comparison of specific energy at upstream and downstream of side weir for different passing flows through circular channel

weir is calculated about $2.89 \%$. Thus, in supercritical flow conditions that channel is steep, the specific energy principle is also established and the specific energy value along the side weir is almost constant.

\section{Effect of channel slope on specific energy}

In Table 5, the specific energy value at the upstream and the downstream end of the side weir for a channel with three different slopes is shown. In this simulated model, the boundary conditions, the mesh size of the computational domain and the hydraulic conditions of the numerical model are considered constant and only the channel bed slope increases. As shown, by increasing the circular channel bed slope the specific energy value increases. An important point that should be noted is that despite a fourfold increasing of the main channel bed slope, the specific energy value at the upstream and downstream sections of the side weir is almost constant. Therefore, the constant specific energy principle along the side weir for different slopes of the main channel is also established.

\section{Effect of main channel bed slope on S3 profile slope}

Generally, in the supercritical flow regime, a S3 profile is formed at the downstream of the side weir. In this numerical study, the $\mathrm{S} 3$ profile slope is introduced by $\theta$ (Fig. 2). In Fig. 9, the 3D view of the simulated free surface of the

Table 5 Changes in simulated specific energy for main channel with different slopes

\begin{tabular}{llll}
\hline$S_{0}$ & 0.005 & 0.01 & 0.02 \\
\hline$E_{1}(\mathrm{~m})$ & 0.1867 & 0.1931 & 0.2081 \\
$E_{2}(\mathrm{~m})$ & 0.1836 & 0.1926 & 0.2050 \\
\hline
\end{tabular}


supercritical flow along the side weir and the formation process of the S3 profile is shown. As it can be seen, the flow height at the side weir downstream reaches to its lowest value and then flow connects to the tailwater depth using the $\mathrm{S} 3$ profile.

In Table 6, the changes in the S3 profile slope versus the main channel bed slope are provided. As shown, by increasing the main channel bed slope $\left(S_{0}\right)$, the $\mathrm{S} 3$ profile slope value $(\theta)$ decreases and the flow drops at the side weir end connects to the tailwater depth with a milder slope.

\section{Conclusions}

Side weirs are used as flow control structures in flood control projects, drainage networks and irrigation lands. Circular channels are widely used in sewage disposal networks. In practice, flood flows, catchment from dams and flows within transmission lines are supercritical. In this numerical modeling, the turbulence and the flow field passing through the circular channel with side weir in supercritical flow conditions were simulated using the FLOW-3D model. The changes in the free surface of the numerical model and the flow turbulence were simulated using the VOF method and the RNG $k-\varepsilon$ model, respectively. In this numerical study, the comparison of the flow free surface, the discharge coefficient of the side weir $\left(C_{d}\right)$, the Froude number of the side weir upstream end $\left(F_{1}\right)$, the passing discharge over the side weir $\left(Q_{w}\right)$ and the specific energy at the weir upstream indicated a good agreement between the numerical model and experimental results in predicting the flow characteristics. Then, the effects of circular channel slope change on transverse and longitudinal
Table 6 Changes in S3 profile slope versus main channel bed slope

\begin{tabular}{llll}
\hline$S_{0}$ & 0.005 & 0.01 & 0.02 \\
\hline$\theta(\mathrm{rad})$ & 0.0187 & 0.0179 & 0.01
\end{tabular}

flow profiles along the side weir in supercritical flow conditions were investigated. By increasing the main channel bed slope, the flow depth decreases although this depth decreasing is negligible. Increasing of circular channel bed slope causes reduction in the passing discharge over the side weir and in opposite, the Froude number of the side weir upstream end increases. By increasing the bed slope, the calculated discharge coefficient by Uyumaz and Muslu (1985) shows a decreasing trend. Analysis of the numerical model results shows that the specific energy value at the upstream and downstream ends of the side weir in supercritical flow conditions is almost constant and the specific energy average difference between the beginning and the end of the weir was calculated equal to $2.89 \%$. Then, the effects of the circular channel bed slope change on the specific energy value were investigated, so that the analysis of the numerical results showed increasing trend of the specific energy by increasing of the main channel bed slope. In supercritical flow conditions and steep channels with side weir, the flow depth at the weir downstream end reaches to its lowest value, and then, this depth is connected to the tailwater depth by the S3 profile. Finally, the effects of the main channel bed slope changes on the S3 profile slope were investigated and it was concluded that the increase in the circular channel bed slope $\left(S_{0}\right)$ leads to the decrease in the $\mathrm{S} 3$ profile slope $(\theta)$.

Fig. 9 3D view of flow free surface along the side weir and $\mathrm{S} 3$ profile formation process

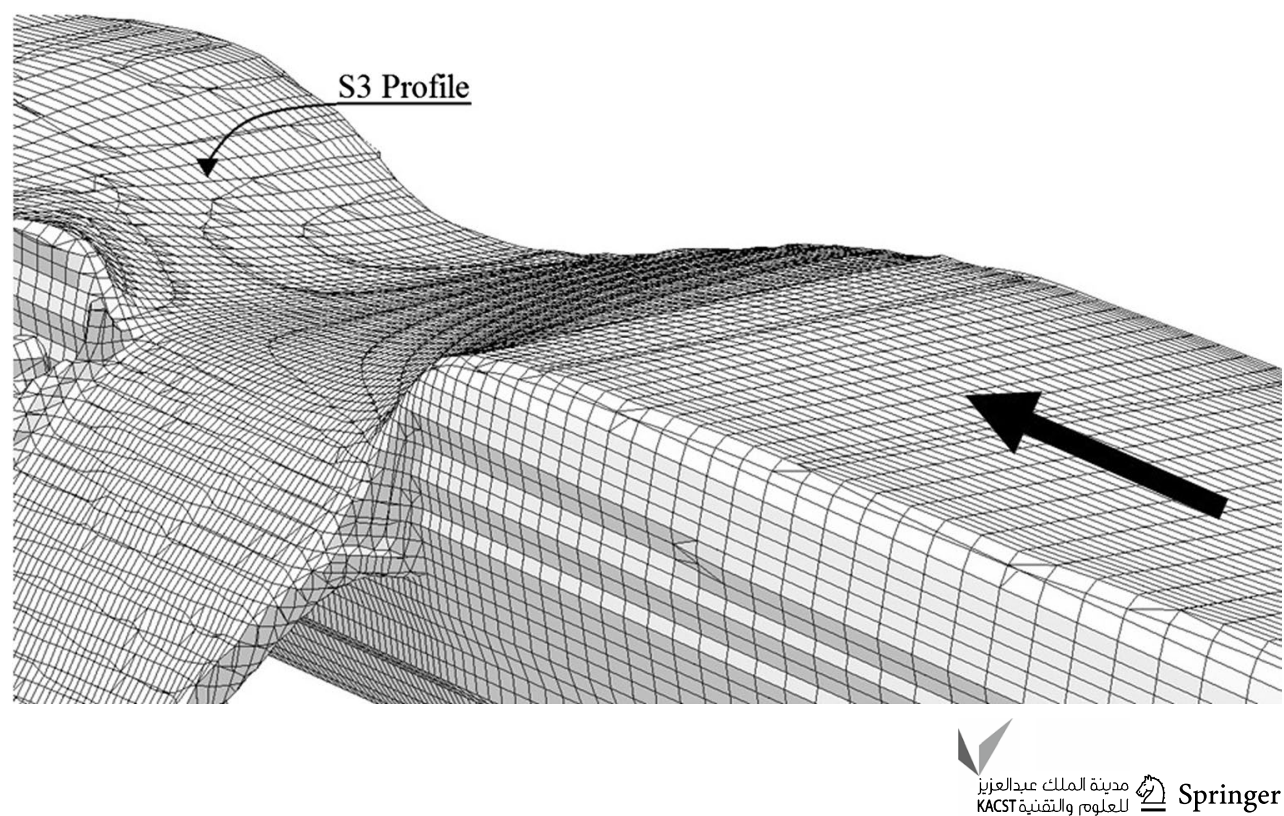




\section{Compliance with ethical standards}

Conflict of interest All authors declare they have no conflict of interest.

Open Access This article is distributed under the terms of the Creative Commons Attribution 4.0 International License (http://creativeco mmons.org/licenses/by/4.0/), which permits unrestricted use, distribution, and reproduction in any medium, provided you give appropriate credit to the original author(s) and the source, provide a link to the Creative Commons license, and indicate if changes were made.

\section{References}

Ackers P (1957) A theoretical consideration of side-weirs as storm water overflows. Proc Inst Civ Eng 6:250-269

Allen JW (1957) The discharge of water over side weirs in circular pipes. ICE Proc 6(2):270-287

Aydin MC (2012) CFD simulation of free-surface flow over triangular labyrinth side weir. Adv Eng Softw 45:159-166

Aydin MC, Emiroglu ME (2013) Determination of capacity of labyrinth side weir by CFD. Flow Meas Instrum 29:1-8

Azimi H, Shabanlou S (2015) The flow pattern in triangular channels along the side weir for subcritical flow regime. Flow Meas Instrum 46:170-178

Azimi H, Shabanlou S, Salimi MS (2014) Free surface and velocity field in a circular channel along the side weir in supercritical flow conditions. Flow Meas Instrum 38(1):108-115

Bagheri S, Heidarpour M (2012) Characteristics of flow over rectangular sharp-crested side weirs. J Irrig Drain Eng 138(6):541-547

Borghei SM, Jalili MR, Ghodsian M (1999) Discharge coefficient for sharp crested side-weirs in subcritical flow. J Hydraul Div 125(10):1051-1056

Cheong H (1991) Discharge coefficient of lateral diversion from trapezoidal channel. J Irrig Drain Eng 117(4):461-475

Coonrod J, Ho J, Bernardo N (2009) Lateral outflow from supercritical channels. In: Proceedings of the 33rd international association of hydraulic engineering \& research (IAHR) congress: water engineering for a sustainable environment, IAHR, Madrid, pp 123-130

El-Khashab AMM (1975) Hydraulics of flow over side weirs. Ph.D. thesis, University of Southampton, Southampton

El-Khashab A, Smith KVH (1976) Experimental investigation of flow over side weirs. J Hydraul Div 102(9):1255-1268

Emiroglu ME, Kaya N, Agaccioglu H (2010) Discharge capacity of labyrinth side weir located on a straight channel. ASCE J Irrig Drain Eng 136(1):37-46

Emiroglu ME, Agaccioglu H, Kaya N (2011) Discharging capacity of rectangular side weirs in straight open channels. Flow Meas Instrum 22:319-330

Ghodsian M (2003) Supercritical flow over a rectangular side weir. Can J Civ Eng 30:596-600

Hager WH (1982) Die Hydraulik von Verteilkanaelen (in German). Teil 1-2, Mitteilung Nr.55 56, Versuchanstalt fur Wasserbau, Hydrologie und Glaziologie, ETh, Zurich

Hager WH (1994) Supercritical flow in circular-shaped side weir. J Hydraul Eng 120(1):1-12

Jalili M, Borghei SM (1996) Discussion discharge coefficient of rectangular side weirs. ASCE J Irrig Drain Eng 122(4):132

Khorchani M, Blanpain O (2004) Free surface measurement of flow over side weirs the video monitoring concept. Flow Meas Instrum 15(2):111-117
Mizumura K, Yamasaka M, Adachi J (2003) Side outflow from supercritical channel flow. J Hydraul Eng 129(10):769-776

Mohammed AY (2015) Numerical analysis of flow over side weir. J King Saud Univ Eng Sci 27(1):37-42

Muslu Y (2001) Numerical analysis for lateral weir flow. J Irrig Drain Eng 127(4):246-253

Muslu Y, Tozluk H, Yüksel E (2003) Effect of lateral water surface profile on side weir discharge. J Irrig Drain Eng 129(5):371-375

Nandesamoorthy T, Thomson A (1972) Discussion of spatially varied flow over side weir. ASCE J Hydraul Div 98(12):2234-2235

Novak G, Kozelj D, Steinman F, Bajcar T (2013) Study of flow at side weir in narrow flume using visualization techniques. Flow Meas Instrum 29:45-51

Oliveto G, Biggiero V, Fiorentino M (2001) Hydraulic features of supercritical flow along prismatic side weirs. J Hydraul Res 39(1):73-82

Pathirana KPP, Munas MM, Jaleel ALA (2006) Discharge coefficient for sharp-crested side weir in supercritical flow. J Inst Eng 39(2): $17-24$

Qu J (2005) Three dimensional turbulence modeling for free surface flows. Ph.D. thesis, Concordia University, Montreal

Ramamurthy AS, Zhu W, Vo D (1995) Rectangular lateral weirs in circular open channels. J Hydraul Eng 121(8):608-612

RangaRaju KG, Prasad B, Gupta SK (1979) Side weir in rectangular channel. J Hydraul Div 105(5):547-554

Rao KH, Pillai CR (2008) Study of flow over side weirs under supercritical conditions. Water Resour Manage 12:131-143

Singh R, Manivannan D, Satyanarayana T (1994) Discharge coefficient of rectangular side-weirs. J Irrig Drain Eng 120(4):814-819

Subramanya K, Awasthy SC (1972) Spatially varied flow over sideweirs. J Hydraul Div 98(1):1-10

Tadayon R (2009) Modelling curvilinear flows in hydraulic structures. $\mathrm{Ph}$.D. thesis, Concordia University, Montreal

Uyumaz A (1992) Side weir in triangular channel. J Irrig Drain Eng 118(6):965-970

Uyumaz A (1997) Side weir in U-shaped channels. J Irrig Drain Eng 123(7):639-646

Uyumaz A, Muslu Y (1985) Flow over side weirs in circular channels. J Hydraul Eng 111(1):144-160

Uyumaz A, Smith RH (1991) Design procedure for flow over side weirs. J Irrig Drain Eng 117(1):79-90

Vatankhah AR (2012a) Water surface profile over side weir in a trapezoidal channel. Proc Inst Civ Eng (ICE) Water Manag 165(5):247-252

Vatankhah AR (2012b) Analytical solution for water surface profile along a side weir in a triangular channel. Flow Meas Instrum 23(1):76-79

Vatankhah AR (2012c) New solution method for water surface profile along a side weir in a circular channel. J Irrig Drain Eng 138(10):948-954

Vatankhah AR (2013) Water surface profiles along a rectangular side weir in a U-shaped channel. J Hydrol Eng 18(5):595-602

Vatankhah AR, Bijankhan M (2009) Discussion of 'method of solution of non-uniform flow with the presence of rectangular side weir. J Irrig Drain Eng 135(6):812-814

Yu-Tech L (1972) Discussion of spatially varied flow over side weir. ASCE J Hydraul Div 98(11):2046-2048

Publisher's Note Springer Nature remains neutral with regard to jurisdictional claims in published maps and institutional affiliations. 